\title{
$\underline{\mathbf{P}-87}$
}

\section{Standardization of Orthosiphon Stamineus Benth. Leaves Extract for Antioxidant and Cytotoxicity using Brine Shrimp Assay}

\author{
Nur Farah Amalina Mughni, Fatin Fathiah and Zhari Ismail
}

School of Pharmacy, Universiti Sains Malaysia, 11800 Pulau Pinang; E-mail: malina_farra@yahoo.com.my

Orthosiphon stamineus (Lamiaceae) or Misai Kucing is one of the invaluable medical plants originated from Southest Asia and were used for various ailments. Essential cytotoxicity data regarding the relationship between antioxidant activity and brine shrimp lethality bioassay of $O$. stamineus leaves extract is lacking. Standardised methanol extracts samples of $O$. staminues leaves from ten different locations namely Kepala batas (Penang), Hulu Langat (Selangor), Sungai kok (Terengganu), Sungai udang (Melaka), Desaru (Johor), Sendayan (N. Sembilan), Changkat Jering (Perak), Pasir Putih (Kelantan), Taiping (Perak) and Seremban (N. Sembilan) were evaluated for extract standardization using selected marker compounds sinensetin, eupatorin and rosmarinic acid.The result revealed the percentage of marker compound contain in the leaves for each location. Plant from Sendayan gave the highest percentage for seninsetin (1.04\%) and eupatorin $(1.0 \%)$. The methanol extracts were then subjected for antioxidant activity by using DPPH, $\beta$-carotene and xanthine oxidase assays. All samples showed significant antioxidant activity in all assay techniques. All samples were subjected to a study to detect cytotoxic activity using the brine shrimp lethality bioassay. The samples exhibit significant toxicity results for long-term exposure $\mathrm{LC}_{50} \mathrm{Within} 29 \mu \mathrm{g} / \mathrm{ml}$ to $157 \mu \mathrm{g} / \mathrm{ml}$ for 24 hours.

Keywords: Standardised extract, Orthosiphon stamineus, different source, antioxidant, brine shrimp. 